University of Louisville

ThinkIR: The University of Louisville's Institutional Repository

$12-2015$

\title{
Russian energy rents and the eastward pivot : examining the role of Russia's oil and gas industry in its foreign policy behavior.
}

\author{
Kara Stivers \\ University of Louisville
}

Follow this and additional works at: https://ir.library.louisville.edu/honors

Part of the Political Science Commons

\section{Recommended Citation}

Stivers, Kara, "Russian energy rents and the eastward pivot : examining the role of Russia's oil and gas industry in its foreign policy behavior." (2015). College of Arts \& Sciences Senior Honors Theses. Paper 118.

http://doi.org/10.18297/honors/118

This Senior Honors Thesis is brought to you for free and open access by the College of Arts \& Sciences at ThinkIR: The University of Louisville's Institutional Repository. It has been accepted for inclusion in College of Arts \& Sciences Senior Honors Theses by an authorized administrator of ThinkIR: The University of Louisville's Institutional Repository. This title appears here courtesy of the author, who has retained all other copyrights. For more information, please contact thinkir@louisville.edu. 
Russian Energy Rents and the Eastward Pivot: Examining the Role of Russia's Oil and Gas Industry in Its Foreign Policy Behavior

Kara Stivers

Submitted in fulfillment of the University of Louisville Senior Honors Thesis

Completed Under the Direction of Dr. Charles Ziegler

Fall 2015 


\section{Introduction}

Spanning 11 time zones and home to over 143 million people, the Russian Federation holds a prominent position on the world stage. It wields veto power on the UN Security Council, maintains one of the largest existing nuclear arsenals, and is one of the top three energy producers in the world. Indeed, recent world events have put Russia into the headlines so often that an introduction to the country seems almost superfluous. However, while many are familiar with the country itself, understanding the behavior of the Russian Federation is an entirely different matter.

Numerous experts and scholars have tried with varying success to make sense of the country, and scholars have often been both fascinated and frustrated in their attempts to explain and predict Russia's domestic and foreign policy behavior. Thus, this paper joins an already immense body of scholarship and literature in its efforts to try to understand the Russian Federation. Yet while recognizing the extensive work that has already been completed, this paper will seek to create and advance new arguments by building on existing theories, and applying them to current events.

The topic of Russian energy policy is a subject of concern for many countries. Scholars such as Thane Gustafson and Marshall Goldman have written excellent, extensive works on the role energy has played in both holding Russia together, and in shaping its interactions with the rest of the world. However in this ever changing political and economic environment, with the Russian government struggling to overcome low oil prices, budget deficits, and external sanctions over actions in Ukraine, new scholarship is needed on the impacts of these events on Russia's foreign policy trajectory. 
This paper will seek to show how Russia's continued stability as a state is directly tied to the rents associated with the Russian oil and gas industry, through a basic framework comprised of three main arguments. First, that Russian natural resources are not inherently a curse, and have been used in a beneficial way by the ownership structure in power, even during Soviet times, to drive technology and knowledge, and develop economic ties with other countries.

Second, and building off the previous statement, that Russia is a rentier state today, but it is the way in which those rents have been utilized that has defined the way the oil and gas industry has come to play a role in Russian foreign policy. Oil and gas rents are a double edged weapon, a tool, that if used correctly, has the potential to bring prosperity and growth to Russia. However, the fact that these rents, and indeed, the broader oil and gas industries, have been used as a means of consolidating power and stability rather than growth and development, means that Russia is moving towards a very different outcome. In other words, it is not natural resources but politics that is Russia's true curse.

This leads to the third point, which is that because Russia has utilized these rents towards consolidating power and security and not towards growth and development, they have actually undermined the very basis for the country's stability. Russia is beginning to experience, and will continue to experience, the opposite of what it wanted in using these resources to consolidate power, and there are signs that it is already being forced to act out of a position of insecurity and instability, especially in foreign policy.

Ultimately this framework suggests that as this short and medium term interdependence continues to be seen in the country's involvement in the evolving crises in Ukraine and in the Middle East, the long term political and economic consequences of these events will materialize 
through the shifting nature of Russia's relationship with countries such as China and Japan, further influencing the country's strategic decision to slowly pivot away from Europe and towards Asia.

\section{Background}

In 2012, disruptions in oil production in places like South Sudan, Yemen, Syria, and the North Sea resulted in upward pressure on the market and played a role in average crude oil prices rising to historically high levels for the second year in a row. ${ }^{1}$ Also in 2012, Vladimir Putin won the presidential election with $64 \%$ of the vote after a hiatus as Prime Minister, and Russia itself, after nineteen years of negotiations, finally joined the World Trade Organization. ${ }^{2}$ Despite the appearance of some mass demonstrations during the winter about the issues of corruption and rule of law, the outlook for Russia, all told, looked surprisingly bright, especially coming after the crisis of 2008-2009. ${ }^{3}$ Indeed, there seemed little cause to heed the gloomy predictions of former Finance Minister Aleksei Kudrin, who was expelled from his place of leadership after falling out of favor with the Kremlin in September $2011 .^{4}$

Kudrin warned that while oil prices had risen dramatically from $\$ 70$ to $\$ 100$ in late 2011, this was not reflected proportionally in Russia's economic growth. ${ }^{5}$ Whereas before, oil at $\$ 60$ dollars a barrel had generated 8\% GDP growth, the nearly doubled price in oil was producing

\footnotetext{
${ }^{1}$ Andrew C. Kuchins, "Russia and the CIS in 2014: A Rather Bad Year." [Asian Survey 55.1 (2015),] 148.; "Crude Oil Prices Peaked Early in 2012." EIA: Independent Statistics and Analysis. [U.S. Energy Information Administration, 21 Aug. 2012.]

${ }^{2}$ Laura Mills, "Russia Joins WTO after 18 Years of Negotiations." [USA Today. USA Today, 22 Aug. 2012.]; Kathy Lally and Will Englund, "Putin Wins Election as Russian President; Opponents Claim Widespread Fraud." Washington Post. [The Washington Post, 4 Mar. 2012.]

${ }^{3}$ Thane Gustafson, Wheel of Fortune: The Battle for Oil and Power in Russia. [Boston: Belknap, 2012.] 492.

${ }^{4}$ Ibid, 492.

${ }^{5}$ Ibid, 491
} 
only half of that number in growth. ${ }^{6}$ According to Kudrin, this was due in part to weak investment, with capital leaving Russia at a rate surpassing even that of the 1990s, but it was also a result of the increasing amount of oil revenues that were being taken by the government's ever expanding budget. ${ }^{7}$

Russia was, in Kudrin's mind, on the path to greater deficits and instability due to the out of control spending, a path that would result in ever increasing dependence on the price of oil. ${ }^{8}$ "If this year it takes oil at $\$ 115$ a barrel to balance the budget," he predicted, "next year it will take about $\$ 122$ a barrel." $" 9$ Yet the problem was even greater than this increased dependence on oil prices. Despite the prices of the time, Kudrin warned that by 2014 , oil prices could return to \$60 a barrel, and the overall share of the oil and gas sector in the country's total GDP would shrink dramatically by 2020 , resulting in a fiscal crisis for Russia. ${ }^{10}$

Kudrin's warnings fell largely on deaf ears, and his proposals for creating a stronger investment climate, and for ending the process of channeling investment through large state corporations, a process he saw as creating both corruption and capital flight, were ignored by the Kremlin. ${ }^{11}$ His call for low inflation, a stabilized currency, and stronger property rights to improve the investment climate and give entrepreneurs incentives for risk-taking ventures was in many ways the last remnants of the market-reform programs of the early 2000s, which had gradually faded away throughout the rest of the decade. ${ }^{12}$ In the end, Kudrin went unheeded, and in the midst of Putin's reelection campaign, a Citigroup Russia report found that fulfilling all of

\footnotetext{
${ }^{6}$ Ibid, 491

${ }^{7}$ Ibid, 491

${ }^{8}$ Ibid, 491

${ }^{9}$ Ibid, 491

${ }^{10}$ Ibid, 491

${ }^{11}$ Ibid, 492

${ }^{12}$ Ibid, 492.
} 
his campaign commitments would require oil prices to be at $\$ 150$ per barrel or higher simply to balance the budget. ${ }^{13}$

Today, Russia's outlook at the end of 2015 looks considerably more grim than it did in 2012. The country's role in the Ukrainian conflict resulted in sanctions from the United States and Europe that put significant pressure on the economy. The decision of OPEC members to cut prices and continue with high levels of production, coupled with the increased production levels of the United States, proved even more devastating, pushing the country into the beginnings of a recession. $^{14}$

\section{Current Literature}

Given this rapid series of events and the correspondingly dramatic change in circumstances, there is little doubt that Russia's oil and gas industry plays a significant part in the country's economy, and more broadly its power on the world stage. Many scholars have debated exactly what the nature of this relationship is, and what it means for Russia's future. Most relevant to the purposes of this paper is the current discussion on the conceptualization of Russia as a rentier state.

In order to understand the literature, it is first important to define a rentier state. Luciani wrote that a rentier state can be identified when a government of any country receives at least $40 \%$ of its revenues in the form of rent. ${ }^{15}$ Beblawi writes more specifically that, "the rents come from abroad, the rents accrue to the government directly, and only a few are engaged in the generation of this rent (wealth,) the majority being only involved in the distribution or utilization

\footnotetext{
${ }^{13}$ Ibid, 492

${ }^{14}$ Andre Tartar,and Anna Andrianova. "Russian Recession Risk Seen at Record as Oil Saps Economy." Bloomberg.com. [Bloomberg, 27 Nov. 2014.]

${ }^{15}$ Giacomo Luciani,"Allocation vs. Production States: A Theoretical Framework." The Arab State. [Berkeley: U of California, 1990,] 72.
} 
of it." ${ }^{16}$ Although rents can be derived from a number of sources, the conceptualization of Russia as a rentier state is framed specifically in terms of natural resources, with rents generated not through aid or human activity, but through the scarcity value of resources such as oil and gas. The implications of a rentier state are described well by Wiktorwricz, who depicts a kind of "rentier social contract" in which "the state provides goods and services to society, while society provides state officials with a degree of autonomy in decision-making." ${ }^{17}$ Ross writes that the primary questions to ask in determining if a country is indeed a rentier state is first, "how does the state collect revenue," second, "how does the state spend revenues," and third, "how does the rentier wealth distort social structure?"18

A wide array of research has been conducted on Russia as a rentier state, with scholars such as Goldman and Gustafson spending significant amounts of attention on the implications of this argument. Indeed, there is a considerable amount of evidence that does seem to indicate Russia possesses the qualities of a rentier state. A 2013 EIA report indicated that revenue from Russia's oil and gas industries comprised almost $70 \%$ of the country's $\$ 515$ billion export revenue, and a little over $52 \%$ of the annual budget for that year alone. ${ }^{19}$ This seems to easily fulfill Luciani's qualifications for the definition of a rentier state. ${ }^{20}$

However, there are a number of different arguments within this conceptualization of Russia as a rentier state. There are those who see this dependence on rents as the absolute and

\footnotetext{
${ }^{16}$ Hazem Beblawi, “The Rentier State in the Arab World”. [Arab Studies Quarterly 9.4 (1987)] 87.

17 Quintan Wiktorowicz, "The Limits of Democracy in the Middle East: The Case of Jordan". [Middle East Journal 53.4 (1999)] 608.

${ }^{18}$ Michael L. Ross, "Does Oil Hinder Democracy?" World Pol. [World Politics 53.03 (2001)] 325.

19 "Oil and Natural Gas Sales Accounted for 68\% of Russia's Total Export Revenues in 2013." U.S. Energy Information Administration. EIA Independent Statistics and Analysis, 23 July 2014.

${ }^{20}$ Luciani, 72.
} 
entirely negative effect of resource abundance..$^{21}$ Often these scholars point to rentier states as being strongly correlated with authoritarianism, a lack of civil society, and high levels of endemic corruption. ${ }^{22}$ Other takes a more mediated position, arguing that the relationship between these natural resources and the rents can be both positive or negative depending upon the politics, systemic structures, or operational controls of the country in question. ${ }^{23}$ Still others argue that though a country may indeed be a rentier state, there is no direct linkage between this fact, and between specific political and economic outcomes, and that there is in fact little correlation between the abundance of natural resources and any kind of predictable outcome for the state itself. ${ }^{24}$

\section{$\underline{\text { Research Methodology }}$}

This paper will be arguing from the second, mediated stance on rentier states, and will approach the issue of understanding the influence of the oil and gas industry in Russian foreign policy from this more nuanced position offered by individuals such as Gustafson, Goldman, Luong, Weinthal, and Dunning. The goal of this research is to provide a method of both testing the applicability of these theories to current world events, and to provide a possible way of understanding the country's current foreign policy trajectory as well as the resulting immediate and long term implications of that foreign policy.

\footnotetext{
${ }^{21}$ Jeffrey Sachs and Andrew Warner. "Natural Resource Abundance and Economic Growth." [Harvard Institute for International Development (1995).]

${ }^{22}$ Mehrzad Javadi Kouchaksaraei and Mohammad Reevany Bustami, "Structural Review of Rent Government and Its Effect on Democracy Process." [Canadian Social Science, 8.6 (2012)]

${ }^{23}$ Pauline Jones Luong, and Erika Weinthal. Oil Is Not a Curse: Ownership Structure and Institutions in Soviet Successor States. [New York: Cambridge UP, 2010.]

${ }^{24}$ Stephen Haber and Victor A. Menaldo, "Natural Resources in Latin America: Neither Curse Nor Blessing," [Oxford Handbook of Latin American Political Economy (2012).]
} 
This will be achieved both through engaging current literature, and by evaluating the current data on Russia's evolving energy relationships with Europe, and with Asian countries such as China and Japan. Russia especially provides a unique opportunity to evaluate the primary arguments of the mediated position on rentier states, due to the changing use of rents before and after the dissolution of the Soviet Union. Ultimately, using Russia as a case study allows for the real life application of this mediated position as it relates to a specific country, and also provides the opportunity to look at how those theories can explain and predict the role of energy in Russian foreign policy as demonstrated through recent events.

\section{A Mediated Understanding of the Rentier State}

Within the nuanced, negotiated understanding of the rentier state are the views of a number of notable scholars who detail in great length exactly how Russia fits into this categorization. Marshall Goldman's book Petrostate, first published in 2008 and then republished in 2010, tells the story of Russia as a "monoculture" that is highly dependent on natural resources, meaning that "a really substantial collapse in energy prices would spell an end to Russia's status as a super energy power." ${ }^{25}$ Yet though the country is "heavily dependent on high energy prices," making this position of power "precarious," Goldman argues that the "benefits that stem from that monoculture have more than offset the disadvantages." ${ }^{26}$ In sum, Russia's status as a major energy producer gave the country "new assertiveness and self-confidence," to which other countries could only "smile and seek to import more of Russia's oil and gas. ${ }^{27}$

\footnotetext{
${ }^{25}$ Marshall I. Goldman, Petrostate: Putin, Power, and the New Russia. [Oxford: Oxford UP, 2008.] 204.

${ }^{26}$ Ibid, 206

${ }^{27}$ Ibid, 209
} 
Thane Gustafson, whose thoughtful and comprehensive analysis Wheel of Fortune was published in 2012, provides a somewhat different perspective on the relationship between these industries and Russia's position of power. Writing at a time when oil prices were at a high, he envisioned a different scenario for Russia's future, stating that "nothing so closely predicts the future of Russia as oil prices." ${ }^{28} \mathrm{He}$ argued that "the forces behind a lower-price scenario are becoming stronger," and "in a world of lower-priced oil and gas, Russia, with its conventional energy signature and its declining legacy, would be squeezed between higher-cost production at home and lower prices for its oil and gas exports." 29

For Gustafson, there is a "mutual dependence of the oil industry and the state," wherein the "fortunes of oil have determined those of the state, while the strength or weakness of the state has shaped the fortunes of the oil industry." 30 The country is akin to a house of cards, becoming "more dependent than ever on exports of oil and gas and other natural resources, while failing to develop the sectors that might export higher-tech goods and services." ${ }^{31}$ Thus, when oil revenues shrink, "Russia with its diminished human and physical capital, will be hard-pressed to keep up with the emerging economies of Asia, as well as the mature knowledge economy of the United States." ${ }^{32}$ Yet even while taking this more pessimistic view of Russia's oil and gas industry, Gustafson nevertheless also believes that Russia's hope lies in this field, as the "fastest ticket to the high-tech future," if industry reforms can be achieved that returns it "to its roots as a

\footnotetext{
${ }^{28}$ Gustafson, 483

${ }^{29}$ Ibid, 486-487

${ }^{30}$ Ibid, 482

${ }^{31}$ Ibid, 488.

${ }^{32}$ Ibid, 494.
} 
knowledge industry," and as a "stimulus for innovation and entrepreneurship throughout the economy." 33

In other words, both Goldman and Gustafson reject the traditional narrative of Russia as being wholly captured by a "resource curse," but neither of them deny that Russia truly is a "rent-based system" in which the flow of energy rents are so "vital to the maintenance of the economy and the political system," that it is not simply "at the heart of the system; it is the heart of the system." 34 Though both men disagree in part about the implications of this system, they both acknowledge that the "key to the fate of Russia is the fate of Russian oil," and that this interdependence has the potential to be both Russia's downfall and its salvation. ${ }^{35}$

Thad Dunning's work supplements this by dividing states into resource abundant, rentier, and resource dependent states, and advances the argument that rentier states are not inherently plagued by a resource course that leads to authoritarianism. ${ }^{36}$ Rather, the power ultimately lies with the political elite, whose interests are paramount in determining how these resources shape the political future of the country. ${ }^{37}$

Pauline Luong and Erika Weinthal also make a similar argument in their book Oil is not a Curse, stating that it is the political system that is most responsible for how a rentier state operates, not a so called "curse" of the natural resources. ${ }^{38}$ They note specifically that, "the influence of ownership structure in particular is apparent in the growing ease with which the

\footnotetext{
${ }^{33}$ Ibid, 497.

${ }^{34}$ Ibid, 25.

35 Ibid, 27.

36 Thad Dunning, "Resource dependence, economic performance, and political stability." [Journal of Conflict

Resolution 49 (4)]; Thad Dunning, Crude Democracy: Natural Resource Wealth and Political Regimes. [Cambridge: Cambridge UP, 2008.] 1-25.

${ }^{37}$ Ibid, 1-25.

${ }^{38}$ Luong and Weinthal, 335.
} 
Putin administration utilized rents for political purposes once it asserted full state ownership and control over the gas sector." ${ }^{39}$ In other words, both authors counter traditional narratives about the "resource curse" and "rentier states" by arguing that countries with natural resources are not cursed by those resources, but by the ownership structure used to manage those resources. ${ }^{40}$ Gel'man and Marganiia add to this general concept, giving it the term the "conditional resource curse." 41

\section{$\underline{\text { Russia's Development as a Rentier State }}$}

One of the strongest reasons this negotiated understanding of a rentier state fits Russia's current position is because this negative impact of overreliance on rents has been a relatively new development over the past several decades of Russian history. Scholars such as Thane Gustafson and Per Högselius have noted the positive aspects of the development of oil and gas during the Soviet era. In his book Red Gas, Högselius provides a comprehensive and thorough evaluation of how gas served as a point of connection between the Soviet Union and Europe, even at the height of the Cold War. ${ }^{42}$ He notes that the legacy of the natural gas ties between Russia and countries like Germany was one of technological and and economic integration. ${ }^{43}$ "Western Europe's fear of falling victim to intentional supply disruptions from the East did not materialize during the Cold War," Högselius writes, and "as for unintended failures," the Kremlin chose to deprive domestic markets when faced with "the delicate choice of either

\footnotetext{
${ }^{39}$ Ibid, 335.

${ }^{40}$ Ibid, 335; Dunning, Crude Democracy 1-25.

${ }^{41}$ Vladimir Gel'man, and O. Marganiia, Resource Curse and Post-Soviet Eurasia: Oil, Gas, and Modernization. [Lanham: Lexington, 2010,] 6.

${ }^{42}$ Per Högselius, Red Gas: Russia and the Origins of European Energy Dependence. [New York: Palgrave Macmillan, 2013.] 7-11.

${ }^{43}$ Ibid, 7-11.
} 
breaking their export commitments or sacrificing domestic needs. ${ }^{״ 4}$ Indeed, the Soviet Union "earned a reputation for being a trustworthy partner," especially in comparison to other suppliers such as Algeria, Libya, and even Norway. ${ }^{45}$

For Högselius, Soviet gas was used not to consolidate power, but as an economic tool, and as a means of maintaining respect and reputation on the international stage. ${ }^{46}$ As such, it represented a point of economic, political, and technological integration between the USSR and Europe, offering a positive bridge of system building across the Iron Curtain, despite the politics of the time. ${ }^{47}$

Gustafson makes a similar point about Soviet oil. He argues that "the tight intertwining of oil and politics" is in fact "a phenomenon of the final Soviet decade and the post-Soviet transition." ${ }^{48}$ He states that "the Soviet Union was not a petro-state," though "post-Soviet Russia is increasingly taking on the characteristics of one. ${ }^{, 49}$ For Gustafson, the Soviet Union was not reliant on oil or natural resources, until its last decade and a half, after the leaders began to "use oil and gas exports" in order to prop up "their sagging system while avoiding change." 50 This was in large part due to the oil shocks of 1973, and of 1979-1980 which created this possibility through a "massive increase in oil prices - and in Soviet oil revenues." ${ }^{51}$ As Gustafson notes wryly, "ironically, a system that had been built around the principle of autarky, in which foreign

\footnotetext{
${ }^{44}$ Ibid, 232-233.

${ }^{45}$ Ibid, 232.

${ }^{46}$ Ibid, 7-11.

${ }^{47}$ Ibid, 7-11.

${ }^{48}$ Gustafson, 482.

${ }^{49} \mathrm{Ibid}, 482$.

${ }^{50}$ Ibid, 6.

${ }^{51}$ Ibid, 6.
} 
trade traditionally played the role of residual, came to depend for its stability on a global windfall over which the Soviet central-planning system had no control." 52

Both scholars acknowledge that though the state was able to gain a significant amount of rents from these natural resources, these rents were, for the majority of the Soviet Union's existence, not used merely to consolidate control. Rather, they were economic and technological drivers of development, supplementing growth rather than hindering it. Indeed, even though the last decade of the Soviet Union brought on an unprecedented dependence on oil rents, this reliance "even at the end, was not as central as today's." 53 Instead, "what set the stage for Russia's present massive dependence was the implosion of the Soviet industrial system," and while "corruption has spread, budgetary discipline has loosened," and "reforms have been slowed down or frozen," it was not oil and gas that caused these problems. Rather, natural resources have "merely amplified" these already existing issues, meaning that "the impact of oil" primarily depends not on the oil itself but on "how you got it and what you do with it." 54

For both Högselius and Gustafson, "the story of the post-Soviet industry is largely that of the battle for rents," and it was in this post-Soviet environment that the primary changes in the way these rents were allocated began to shift. ${ }^{55}$ During the 1990 s, these rents were claimed by oligarchs and businesses, but by "the first decade of the $2000 \mathrm{~s}$, the state had succeeded in recapturing the lion's share" of these rents. ${ }^{56}$ In large part, this was due to the leadership and

\footnotetext{
${ }^{52}$ Ibid, 6.

${ }^{53}$ Ibid, 6.

${ }^{54}$ Ibid, $6,8$.

${ }^{55}$ Ibid, 24-25.

${ }^{56}$ Ibid, 24.
} 
influence of Putin in trying to restore stability and security to the country after the wild chaos of the 1990 s, a decade that rocked the country both politically and economically. ${ }^{57}$

This historical development aligns well with Karl's theories on the emergence of rentier states from weak institutional frameworks. ${ }^{58}$ As the Soviet Union became increasingly unhinged during the 1980s and 1990s, and the policy reforms under Yeltsin did little to remedy this instability, the origins of Russia's development of a rentier state were truly formed. ${ }^{59}$ Ultimately, this development needed only a leader such as Putin to bring the institutional context necessary for transforming the rents of the oil and gas industry into a political weapon and foreign policy tool he could leverage in creating a strong and unchallenged presidency. ${ }^{60}$

A number of scholars have spent a considerable amount of research on exactly how these energy rents have been used in this capacity. Many have begun by evaluating a thesis supposedly written by Putin early in his career, (though in actuality it may have been written by someone else under his name,) that seems to indicate oil and gas rents were already on the current president's mind long before now. ${ }^{61}$ In the paper, Putin argued that Russia's natural resources should be a primary driver of the country's economic development and its international position, with state planning at the core of Russia's management of these resources. ${ }^{62}$

Several years into Putin's presidency, Martha Olcott, in collaboration with a number of other research partners conducted a study to discover if Putin had followed the strategy outlined

\footnotetext{
${ }^{57}$ Ibid, 24.

58 Terry Lynn Karl, The Paradox of Plenty: Oil Booms and Petro-states. [Berkeley: U of California, 1997] xvii.

${ }^{59}$ Gustafson, 24.

60 ibid, 24.

${ }^{61}$ Martha Brill Olcott, "The Energy Dimensions in Russian Global Strategy: Vladimir Putin and the Geopolitics of Oil," [James A Baker III Institute of Public Policy (2004)] 16-17.

62 Ibid, 16-17.
} 
in this thesis. ${ }^{63}$ The 2004 report found that Vladimir Putin had "gained better control of the levers of power," using the methods foreshadowed in this work. ${ }^{64}$ It also found that by consolidating control of these rents, "Russia's oil and gas reserves" had become "an attractive lever for use in Russia's foreign relations," and that Putin showed no indication that he was "willing to give up control of such lucrative and potentially authoritative instruments of power." ${ }^{965}$

The Brookings Institute then published a report a year later in 2006, which came to the conclusion that the "Russian economy depends not merely on exports, but on the total value of all oil and gas produced." ${ }^{66}$ In other words, Russia not only receives values from the price of resources, but it also benefits from the excesses of that price, a sum otherwise known as windfall profit. ${ }^{67}$ Some of that windfall is retained by owners and a large majority is collected by the state through taxes, duties, and fees, but there is also a large amount of the windfall that is distributed informally. ${ }^{68}$ (See Figure 1)

This is important, because as Gavin Wright writes in his article, there is a significant danger when a nation devotes too much effort to dividing up the bounty of the resource wealth, and not enough effort in creating the bounty, or ensuring the sustainability of the resource sector. ${ }^{69}$ Unfortunately, as the Brookings Institute found, even as early as 2006, Russia was already facing this danger as the elites concentrated "their efforts on gaining control over resource rents to the detriment of policies that could ensure continued reproduction of resources and the rents

\footnotetext{
${ }^{63}$ Ibid, 16-17.

${ }^{64}$ Ibid, 2.

${ }^{65}$ Ibid, 3.

${ }^{66}$ Ibid, 3.

67 “The Russian Federation,” The Brookings Foreign Policy Studies Energy Security Series. [Washington D.C.: Brookings Institution, 2006.] 7-10.

${ }^{68}$ Ibid, 7-10.

${ }^{69}$ Gavin Wright, "Resource-based Growth Then and Now," [Stanford University, June 2001] 24.
} 
they bring." ${ }^{70}$ According to the report, "the real issue at the heart" of the YUKOS affair, for example, was "the redistribution of Russia's oil assets and windfall profits," a fact demonstrated by the "eventual incorporation of YUKO's major production subsidiary Yuganskeneftegaz into the state-dominated oil company Rosneft."71

This growing pattern of rents as a means of power for Putin and his political entourage led Richard Sakwa to comment in his recent books that, "given United Russia's dependence on the politics of patronage, it remains an open question" whether the government will have "a solid basis of political support" if "the regime can no longer rely on its natural resource rents to minimize distributional conflict."72

\section{Putin's Foreign Policy}

So if Russia has slowly transformed into a rentier state under Putin's leadership, what does Russia's current foreign policy reveal about the nature of that state? As Sakwa hints, one of the big questions is how Putin can continue to maintain domestic support now that the amount of rents has been so reduced from the previous levels of the past. Leon Aron expanded on this question, presenting in clear terms Russia’s current dilemma. As he writes, the "dangerous political legacy of the Russian petro-gas state is the centrality of oil and gas revenues," to "the loyalty of two groups that are essential for the regime's survival," namely "the lower-income and elite segments" of society."73 As a result, "reducing dependence on oil and gas revenue" would "mean sweeping and politically fraught reforms in welfare and pension systems," as well as “cutting back on subsidies to Russia's poorer regions," a "sharper reduction in military

\footnotetext{
70 "The Russian Federation," 17.

${ }^{71}$ Ibid, 17.

${ }^{72}$ Richard Sakwa, Power and Policy in Putin's Russia. [Abingdon: Routledge, 2009.] 107.

${ }^{73}$ Leon Aron, "The Political Economy of Russian Oil and Gas." AEI. [American Enterprise Institute: 29 May 2013.] Web.
} 
expenditures," and an overhaul of "the taxation system," all of which would "erode the Kremlin's control over the economy, courts, and inevitably, politics." 74

Now, in the face of lower oil and gas revenues, Putin's choice not to implement such reforms "carries enormous social and political risks." 75 As Aron notes, the impact of lower oil and gas revenues is becoming especially evident on the "already very modest expenditures on health care and education," especially given the country's nearly "bankrupt state pension fund and a rapidly aging population." 76 Moving forward, there is also the significant possibility that these lower prices will also jeopardize the "regime's ability to subsidize the costs" of "soaring household utility prices." 77

Even more concerning for internal stability however, is the potential loss of funds to regions like the North Caucasus, where subsidies from Russia amount to nearly $90 \%$ of the republic's budget, and help the current leader Ramzan Kadyrov in controlling a potentially volatile region filled with "low-intensity fundamentalist" uprisings, and "plagued by unemployment especially among young males."78

Closer to Putin himself, the decline in rents could also result in the "Kremlin's declining ability to secure the elites' loyalty." 79 If those within Putin's inner circle of elites feel they are losing out on their share of the rents, there is a much greater chance that "squabbles" will erupt between them as they seek to "secure the same share of a diminishing pie," thereby "threatening the stability of the regime." 80

\footnotetext{
${ }^{74}$ Ibid.

${ }^{75}$ Ibid.

${ }^{76} \mathrm{Ibid}$.

${ }^{77}$ Ibid.

${ }^{78}$ Ibid.

${ }^{79}$ Ibid.

${ }^{80}$ Ibid.
} 
Given these potential challenges to stability, and Putin's unwillingness to implement any kinds of reforms that would lessen his own political power, many scholars have seen Putin's increasingly aggressive foreign policy as an attempt to find a new source of performance legitimacy. According to Hutcheson and Petersson, the Ukraine crisis in 2014 came after "Vladimir Putin's previously high approval ratings had reached their lowest point in 15 years." 81 They argue that "to the extent that economic growth is beginning to diminish and cynicism about the ability of the president to tackle domestic social and economic problems has increased," Putin's decision to focus on “a stronger projection of Russia’s interests against perceived enemies abroad," is in fact "a logical response to head off a potential regime crisis." 82

In evaluating a considerable amount of survey data, they find that "the assertive foreign policy" has "succeeded" in "stemming the fall in the president's popularity and given a short-term boost to the system's legitimacy." ${ }^{83}$ However, they note that "it is a risky policy, and whilst the reprobation of the West has temporarily allowed Putin to shore up his domestic role against that threat, a leadership crisis may be in the offing if the economic consequences prove more negative than expected." 84

Fiona Hill goes even farther, in her 2014 article, by crediting the economic concerns as influencing this foreign policy course even before the start of the conflict in Ukraine. She argues that in many ways, the “current crisis in Ukraine was triggered by Putin's attempts to bolster the Russian economy." 85 She argues that Putin sensed the looming economic threat, making him

\footnotetext{
${ }^{81}$ Derek S. Hutcheson and Bo Petersson. "The Three 'pillars of Putinism' and Their Role in the Crisis in Ukraine." [Swedish Network for European Studies in Political Science (SNES) Annual Conference (2015)] 2.

${ }^{82}$ Ibid, 2.

${ }^{83}$ Ibid, 2.

${ }^{84}$ Ibid, 20.

${ }^{85}$ Fiona Hill,"Mr. Putin and the Art of the Offensive Defense: Observations on the Crisis in Ukraine and Crimea (Part Two)." The Brookings Institution. [Brookings Institution: 16 Mar. 2014.]
} 
especially fixated on the concept of the Eurasian Union, and resulting in exacerbated tensions over Ukraine's negotiations with the European Union, even before the outbreak of protests and the eventual conflict. ${ }^{86}$

Outside of the Ukrainian crisis, the close ties between economic dependence on rents and Putin's foreign policy can also be seen more broadly in what is perhaps one of the most striking developments since the collapse of the Soviet Union, which is the use of the oil and gas as political leverage. As noted previously, the Soviet Union used these resources as a method of developing economic ties with Europe, and to spur technological growth and development.

According to a Swedish Defense Industry report however, from 1991 to 2007, there have been 55 incidents in which energy supplies have been disrupted, with approximately 36 of them closely corresponding to political incidents taking place at the same time. ${ }^{87}$ In general, most of these political disputes involved former post-Soviet states, with Russia stressing, often correctly, the debts owed by these states and the highly subsidized gas prices they have continued to enjoy even after the dissolution of the Soviet Union. ${ }^{88}$ However, the fact remains that Russia has not attempted to maintain the image of itself as a reliable partner to the same extent as the former Soviet Union.

This change in direction is highlighted perhaps most clearly by Kliment, who argues that "Putinism is no longer advanced by the promise of economic growth," and therefore Russia's leader is instead portraying his authority in terms of a "vigorously revanchist message framed in terms of popular will and historical grievances." 89 The problem, as Kliment notes, is that

\footnotetext{
${ }^{86}$ Ibid.

${ }^{87}$ Jakob Hedenskog and Robert L. Larsson, "Russian Leverage on the CIS and the Baltic States," [FOI-Swedish Defense Research Agency, (2007)] 27.

88 ibid, 27-56.

${ }^{89}$ Alexander Kliment, "Putin's Fairy Tale." [Foreign Affairs. 28 Oct. 2015] n.p.
} 
"Russia's actual room for maneuver is limited both geopolitically and economically," and by pursuing this conceptualization of stability through national sovereignty, "Putin runs the risk of raising expectations that cannot easily be met, while incurring economic damage that cannot easily be repaired." ${ }^{90}$ He concludes that, "a country with an ailing economy cannot afford dreams of revanchist grandeur." 91

In other words, Putin has sought to promote security and stability through a consolidation of domestic power, and has sought to conserve the system rather than enact real reforms to the oil and gas industry. In terms of foreign policy, this has resulted in the oil and gas industries becoming largely a tool and a means of leverage for the state, rather than an industry that promotes growth, economic trade, and technological development for the country.

Unfortunately as a result of this leadership mindset, Russia has become increasingly dependent on the rents from these natural resources, a development that in turn, has undermined the very stability and national sovereignty Putin has sought to promote. Russia's transition to a rentier state, in which the rents are used to consolidate control and obtain political leverage, will not result in the independence and power he has sought on the international stage. Rather, his willingness to promote power consolidation at the expense of growth and development will leave the country even more vulnerable to instability, and eventually, the external pressures of other countries.

\section{The Pivot to Asia}

While many have focused on Russia's interference in Ukraine as a sign of Russia's emerging resurgence and aggression, less attention has been paid to the broader picture in which

\footnotetext{
${ }^{90}$ ibid.

${ }^{91}$ ibid.
} 
this series of events demonstrates the depth of this underlying instability. Sergei Guriev, who although not altogether unbiased in matters regarding the Kremlin, spoke with considerable insight when he said that "having driven the economy into recession, the Russian elite has to find a new way to stay in power," and in trying to act out of this facade of stability and power, Putin "has spawned an aggressive foreign policy to which western leaders are now struggling to respond." 92

The United States and other Western countries have sought to answer this aggression with increasing levels of sanctions designed to create both diplomatic and financial costs for Russia's actions. These sanctions target credit finance, financing to Russian banks and energy companies, as well as the prohibition of "the provision, exportation, or reexportation of goods, services," and "technology in support of exploration or production for deepwater, Arctic offshore, or shale projects that have the potential to produce oil in the Russian Federation." 93 Although some have criticized these sanctions for being ineffective, these highly targeted sanctions have been designed to hit Russia where it is most vulnerable, specifically in relation to the access of technology within the energy industry. Ross Denton of the financial firm Baker \& McKenzie stated in a recent interview that "Russia sanctions have been very cleverly targeted to hit what it wants," which is "Western technology and technological support for its oil and gas industry, which is only available in the U.S, the UK, Europe, and Australia." ${ }^{94}$ As such, Denton predicted that this "clinical use" of these "financial sanctions" would result in the Russian energy sector slowly "dropping off." 95

\footnotetext{
${ }^{92}$ Sergei Guriev,"Corruption Has Laid Waste to the Russian Economy," [Financial Times, 2 Apr. 2014.] n.p.

93 "Ukraine and Russia Sanctions." U.S. Department of State. U.S. Department of State, 2015.

${ }^{94}$ Katy Barnato,"Why Russia Sanctions Are Here for the Long-haul." CNBC. [CNBC: 05 Oct. 2015.]

95 Ibid.
} 
Sarosh Zaiwalla, a senior partner at Zaiwalla \& Co Solicitors which represents Russian and Iranian oil majors, also agreed that these sanctions had hurt Russia's ability to raise long-term funds and invest the huge amounts of money necessary for developing shale and deep-water oil resources. ${ }^{96}$ According to Zaiwalla, the sanctions have "severely impacted the Russian oil industry, cutting it off from the international market and causing the industry to turn inward." ${ }^{97}$ In a recent interview with CNBC, he said that it was due to these sanctions that "major international exploration ventures such as those in the Arctic have suffered, as restrictions on financial and technical assistance have forced oil majors to pull out." $" 98$

Moreover, the sanctions have also directly impacted Russia's energy partnerships with Europe. As Lee and Lukin state, "In the first seven months of 2014, Russia's oil exports to Asia," and "above all China," actually "jumped to record highs." 99 During this same period of time however, "Russian oil exports to Europe fell from a peak of 3.72 million barrels per day in May 2012 to less than 3 million barrels per day in July 2014."100

This does not mean that the energy relationship between Russia and Europe has come to a standstill. Most experts agree that despite European efforts at greater diversification, such as Norway recently overtaking Russia as Western Europe's top gas supplier, Russia will continue to play a pivotal role in supplying energy resources to European countries. ${ }^{101}$ However, the effects of these sanctions are seen elsewhere within the energy industry, and nowhere are they more apparent than in what appears to be Russia's pivot towards Asia, and its efforts towards

\footnotetext{
96 Ibid.

${ }^{97}$ Ibid.

98 Ibid.

${ }^{99}$ Lee and Lukin, Russia's Far East, 143-144.

${ }^{100}$ Ibid, 143-144.

${ }^{101}$ Barbara Lewis and Nerijus Adomaitis. "Norway Overtakes Russia as Western Europe's Top Gas Supplier." Reuters. [Thomson Reuters: 22 May 2015.]
} 
developing greater economic ties with China and Japan. On Monday, November 16th, 2015, for example, Russia and China held the 12th meeting of the Russian-Chinese intergovernmental commission on energy cooperation in Beijing. ${ }^{102}$ At the commission, Russian deputy Prime Minister Arkady Dvorkovich told members of the press that a multinational deal to launch Russia’s Yamal liquefied natural gas (LNG) project was due to be signed in December. ${ }^{103}$ This claim came after previous statements made by Gennady Timchenko, a close political ally of President Putin, and an owner of Novatek, Russia's largest independent gas producer which also controls $60 \%$ of the Yamal project. ${ }^{104}$ He said that his company was in talks with Chinese banks for over $\$ 10$ billion in loans for the Yamal LNG project. ${ }^{105}$ This decision is in many ways a direct result of current US sanctions, since Novatek has been unable to raise long-term loans from capital markets in US dollars, forcing it to turn to Chinese lenders to secure the necessary funding. ${ }^{106}$ In fact, not only has the Yamal project had to obtain the $\$ 10$ billion mentioned by Timchenko, but the project has so far failed to secure the remaining $\$ 15$ billion that would be needed to launch operations. ${ }^{107}$

In some respects, the difficulty obtaining funding is a reflection of the fact that the LNG market of today is quite different than when the project was first proposed by Russia. Projections show that an LNG oversupply will continue until at least 2020, since new projects in Australia, the US and Mozambique are coming on-stream and causing a supply glut. ${ }^{108}$ As a result, Russia's

\footnotetext{
102 "Russia, China Discuss Localization of Manufacturing Some Types of Equipment in Russia." TASS. [TASS, 16 Nov. 2015]

${ }^{103}$ Tim Daiss, "U.S.-Led Sanctions Squeeze Massive Russian Gas Project, But Chinese Funds May Hold The Answer." Forbes. [Forbes Magazine, 18 Nov. 2015.]

${ }^{104}$ Ibid.

${ }^{105}$ Ibid.

${ }^{106}$ Ibid.

${ }^{107}$ Ibid.

${ }^{108}$ Ibid.
} 
continued push for the project shows a certain desperation, one that is not shared by China, and shows just how few other options the country has given the plunge in oil prices and the cut in natural gas prices. ${ }^{109}$

On the one hand, Russia has increasingly become an energy supplier to China, replacing Saudi Arabia twice in 2015 as the biggest seller of crude to China, and at one point reaching a record 4.04 million metric tons or almost 988,000 barrels a day in September. ${ }^{110}$ These numbers are $42 \%$ more than the year before, and have come largely, according to Gao Jian, an analyst at SCI International, as a result of Russia gaining "momentum with its pipeline and buying interest for its crude from teapot refineries." $" 111$ This growth from 2015 to 2014 is made even more significant given that in 2014, imports had already skyrocketed by $36 \%$ since 2013 , and Chinese imports from Saudi Arabia and Venezuela had already dropped by $8 \%$ and $11 \%$ respectively. ${ }^{112}$ Yet on the other hand, much of China's willingness to buy these near record amounts of crude is due to its decision to take advantage of a plunge in prices to boost stockpiles. ${ }^{113}$ So even though Russia has in fact exported more crude to China, China has in some respects benefited more due to these advantageous prices.

Moreover, the major natural gas deal signed in May 2014 would see Russia exporting 38 billion cubic meters per year to China, beginning in 2018, with the possibility of ramping up those numbers to $60 \mathrm{bcm}$ per year at some later point. ${ }^{114}$ Once again however, while this would seem to be a deal in Russia’s favor, both sides agreed on a price between $\$ 9-10$ per million Btu,

\footnotetext{
109 Ibid.

110 "Russia Races Past Saudi Arabia in Tussle for Chinese Oil Market." Bloomberg.com. [Bloomberg, 21 Oct. 2015.]

${ }^{111}$ Ibid.

112 Nick Cunningham, "Russia And China’s Growing Energy Relationship." Oilprice.com. [OilPrice: 28 Jan. 2015.$]$

113 "Russia Races Past Saudi Arabia in Tussle for Chinese Oil Market." 2015.

${ }^{114}$ Cunningham, 2015.
} 
which was much closer to China's preferred price point, and though exact numbers were not disclosed, it is possible that China may have even secured a lower price than Europe pays for Russian gas. ${ }^{115}$

The effect of sanctions can also be seen elsewhere in the energy sector, as Russia seeks to find partnerships and investments outside of Europe and the United States. Recently, Rosneft suspended drilling in the Arctic Kara Sea in 2014, after U.S. ExxonMobil withdrew from the project during sanctions. ${ }^{116}$ As Russian oil companies have been cut off from both foreign financial markets and drilling technologies, Russia has turned to China, and is currently in talks regarding issues like joint production of equipment for the energy industry in Russia. ${ }^{117}$

Yet again however, the unevenness of this relationship is evident through the negotiations between the two countries. Some estimates show that there are approximately $\$ 113$ billion worth of energy sector joint projects in Russia that have been delayed, due not only to sanctions, but also to China's proclivity to play the long game in negotiations. ${ }^{118}$ Gazprom for example, had to set aside hope of receiving a $\$ 25$ billion pre-payment from China to build its $\$ 55$ billion Power of Siberia gas pipeline to China, and the timeline for the project has been moved from 2011 to 2018. ${ }^{119}$ Another route through the Altai is also in question. In fact, of the dozens of joint projects discussed with China over the past 15 years of Putin's leadership, only a few have come into fruition, such as a mid-sized oil pipeline in partnership with Rosneft and Transneft, and China's Sinopec gaining stakes in oil fields along the Volga river. ${ }^{120}$

\footnotetext{
115 Ibid.

${ }^{116}$ Katya Golubkova, "Russia's Rosneft in Talks to Allow China into Offshore Arctic Projects." Reuters. (Thomson Reuters: 16 Nov. 2015.)

117 "Kremlin Pivot to China Slowed as Projects Delayed." Reuters. [Thomson Reuters: 27 Aug. 2015.]

118 Ibid.

119 Ibid.

${ }^{120}$ Ibid.
} 
This patience has worked largely in China's favor. As Alexei Kokin, an analyst with Moscow-based bank Uralsib stated, "China is, of course, interested in getting control of resources but not at any price." Thus, as Sergei Tsyplakov, head of Sberbank OJSC's office in China, notes, "heads of agreements are multiplying at a furious pace," yet "practice shows that out of 10 agreements, we get one or at most two contracts." ${ }^{\prime 21}$ These agreements are non-binding, and tend to languish over time, despite the enthusiasm of the Kremlin. Putin himself has been effusive in discussing energy partnerships with China, even saying in 2014 that while, "we are generally very careful about giving access to our foreign partners," there are "no limitations for our Chinese friends." "122 Yet even this speech, given during an invitation to the China National Petroleum Corporation to be a part of a joint development of the Vankor, the largest greenfield oil development in Russia, demonstrates just how unequal the levels of enthusiasm are between the two countries. While the CNPC did sign an accord with Rosneft, the talks are still continuing today, and little progress has been made towards any further development of the deal. ${ }^{123}$

As a result of their willingness to wait and slow the pace of negotiations, the few deals that have come to fruition have been highly favorable to China. For example, Sinopec and Ronseft agreed on the potential joint development of two fields in East Siberia, in which Sinopec will have the right to buy as much as $49 \%$ of the projects. ${ }^{124}$ Novatek also agreed to sell $9.9 \%$ of the Yamal liquefied natural gas project to China's state-owned Silk Road Fund, a deal that if ratified, would increase China's shareholding in the company to just under a third, since it

\footnotetext{
${ }^{121}$ Ibid.

${ }^{122}$ Elena Mazneva, and Dina Khrennikova, "Putin's China Energy Deals May Hide Paper Tigers as Growth Slows." Bloomberg.com. [Bloomberg: 4 Sept. 2015.]

${ }^{123}$ Ibid.

${ }^{124}$ Ibid.
} 
already owns $20 \%{ }^{125}$ In many cases, the kind of upstream equity stakes in these agreements were something that had been opposed by Russia until recently, demonstrating again that Russia's overall economic and geopolitical position relative to China has weakened considerably. ${ }^{126}$

In fact, previous Russian reluctance went far beyond just upstream equity stakes. In 2002, for example, when Russian company Slavneft was put up for privatization, the Russian government refused to sell it to the China National Petroleum Company, even though they were the highest bidder. ${ }^{127}$ Now however, as Lee and Lukin note in their recent book, one can "speculate" that Russia's pivot towards Asia was already in the works before the Ukrainian crisis. ${ }^{128}$ After all, Russia's 2013 Foreign Policy Concept emphasized that "strengthening Russia's presence in the Asia-Pacific region" was "increasingly important" not only for boosting the "Far Eastern economy" but also for more general "cooperation on a collective basis." ${ }^{129}$ However, "Moscow's deteriorating political relations" with the West over the conflict have "almost certainly accelerated the eastward, mainly Sinocentric, drift of Russian economic policy," making the country much more amenable, and even eager for Chinese participation and investment in Russian energy industries. ${ }^{130}$

As Mankoff writes, the decision to pursue these kind of agreements springs less from an overt animosity towards the Europe and the United States, and more from a growing sense of necessity. After all, as he argues, there is little love lost between China and Russia, since

\footnotetext{
125 Ibid.

${ }^{126}$ Cunningham, 2015.

${ }^{127}$ Lee and Lukin, 101.

${ }^{128}$ Ibid, 142.

129 "Concept of the Foreign Policy of the Russian Federation," [Ministry of Foreign Affairs of the Russian Federation, 2013.]

${ }^{130}$ Lee and Lukin, 142.
} 
"Russia's great-power aspirations are incompatible with excessive dependence on China." 131 Indeed, "given the disparities between a rapidly growing China and a stagnant Russia, their partnership is an unequal one, and Russia's freedom of action is compromised by being overly dependent on China." 132

Most recently, as mentioned previously, the Sino-Russian gas deal that had been in negotiations for decades, finally was agreed upon in terms very much to Russia's disadvantage. It is true that as a result of the deal, China could "become Russia's single largest gas consumer," though "sales to Europe are likely to remain the greatest source of revenue for Gazprom for the foreseeable future." ${ }^{133}$ Yet, as Mankoff notes, "the Ukraine crisis and Russia's fear that Western sanctions would limit its access to European markets made consummating the agreement a higher priority for Moscow," and as a result, "Russia was forced to accept a lower price than it had sought, spend money from its own National Welfare Fund to inject capital into Gazprom to pay for the construction, and allow the Chinese a stake in Russian state oil company Rosneft." 134 In looking towards the future, Mankoff writes that as "Western sanctions continue to target Russia's energy sector," it is probable that Chinese investment is "likely to become even more important to Russia's energy future, at the cost of locking Russia increasingly into dependence on the Chinese market as Europe seeks to reduce its exposure to Russian gas." ${ }^{135}$ In other words, Moscow needs Beijing far more than Beijing needs Moscow. As the United States continues to influence the markets through the shale revolution, and Europe seeks to diversify its energy sources, Russia has been forced to "swallow its concerns about Chinese power out of a

\footnotetext{
${ }^{131}$ Jeffrey Mankoff, "Russia’s Asia Pivot: Confrontation or Cooperation?" [Asia Policy 19.1 (2015),] 67.

132 ibid, 67-68.

${ }^{133}$ Lee and Lukin, 2016. 143.

${ }^{134}$ Mankoff, 74.

135 Ibid, 74.
} 
real fear," that these developments, when coupled with sanctions, could "deepen Russia's isolation." $" 136$

This is not to say that Russia has been looking only towards China as a potential partner in Asia. As Lee and Lukin write, "Japan looks like the most obvious option as a regional counterweight to China," and indeed "some prominent Russian analysts single it out as the most promising Pacific partner" by "suggesting it could become 'Russia's Germany in the East."'137 The reason for this is that, "faced with the post-Fukushima nuclear energy crisis, Japan has had to rely more on fossil fuels," thus "necessitating an increase in imports of oil and natural gas" from Russia. ${ }^{138}$ Moreover, from Russia's perspective, "Japan is the Asia Pacific country" that is most concerned about "the rise of China," providing it with some incentive to "take steps countervailing the growth of Chinese influence."139

Yet, although Russia has sought to triangulate this relationship with China by deepening ties with other countries such as Japan, even these partnerships do not always come at Russia's advantage. It is true, for example, that in 2014, Russia passed Kuwait to become the fourth biggest supplier of crude oil to Japan, with 280,760 barrels per day, which was up by 12 percent from 2013. ${ }^{140}$ Rosneft has also offered Japanese companies a chance to join projects in East Siberia and the Far East, with Chief Executive Igor Sechin telling an industry symposium in Tokyo that they "would like to work with Japan." ${ }^{141}$ His statement to those at the conference was

\footnotetext{
136 ibid, 78.

${ }^{137}$ Lee and Lukin, 243.

${ }^{138}$ Ibid, 243.

${ }^{139}$ Ibid, 243.

140 "Japan's 2015 Crude Imports from Russia May Hit Record High." Reuters. [Thomson Reuters: 11 Mar. 2015.]

141 "Russia's Rosneft Offers Japan Chance to Join East Siberia, Far East Project." RigZone.com. [RigZone: 6 Dec. 2015.]
} 
that "gas resources are available," and that Russia is "ready to satisfy all Japan's gas demands on the account" of Russia's resources. ${ }^{142}$

Yet Russia's interactions with Japan are tainted by "the ill-fated dispute over the South Kurils and Northern territories," as well as a "stagnant Japanese economy," that makes Tokyo a "less attractive partner than it could have been," especially given that "energy consumption" in the country is "going flat and is not going to increase." ${ }^{143}$ Moreover, Russia's trade with Japan often conceals "a highly unbalanced trading relationship, with Russia exporting primarily energy and other raw materials, and importing finished goods," and natural resources constituting "more than $98 \%$ of Russian exports to Japan." 144

In fact, from January to August 2015, despite a mutual decline in trade by $38 \%$, due in part to Japan's participation in Western led sanctions against Russia, as well as reduced demand in Russia itself, Russian oil exports actually increased, rising by $20 \%$ from last year. ${ }^{145}$ In other words, the trading relationship has only become more unbalanced in the past year, especially in light of the fact that "Tokyo's alliance with Washington and its membership in the Group of 7," places "restrictions on how far it can advance economic cooperation with Moscow, at least for the time being." 146

Beyond Japan, Russia has also looked to South Korea, but as Lee and Lukin argue, "Japan and Korea are strong economic players," yet "they may not be able by themselves to effectively counteract China's regional influence and clout." ${ }^{147}$ Thus most of Russia's focus will

\footnotetext{
142 Ibid.

${ }^{143}$ Lee and Lukin, 243.

144 ibid, 71.

145 "Volume of Trade between Russia and Japan down by 38\% in 10 Months 2015." TASS. [TASS: 19 Nov. 2015.]

${ }^{146}$ Lee and Lukin, 243

${ }^{147}$ Ibid, 245.
} 
by necessity be centered on China, meaning that, as Mankoff concludes in his article, Russia's shift to Asia looks to have "significant costs for Russia, especially in terms of the strategic independence that it has long emphasized as the centerpiece of its foreign policy." 148

\section{Moving Forward}

If Mankoff is correct, Russia's evolving relationship with countries such as China and Japan will be marked first and foremost by an inequality in which Russia is at a severe disadvantage. Russia's shift from Europe towards China and Japan has not been taken from a position of power, but from a position of need and insecurity created by an excessive reliance on energy rents to consolidate political control.

Sarah Lain is another scholar who agrees with this assessment. As she writes regarding the recent gas agreement, "Russia's hand was weakened, particularly on the issue of pricing," and due to recent events the country's "potential to work with China as an equal partner has been diminished." 149 She concludes that Russia's concessions puts "Russia on the back foot in the Sino-Russian relationship, making it vulnerable to greater Chinese influence" and relegating it "to a supplier and recipient rather than an equal partner." 150

However not all scholars hold this view of Russia's evolving relationship with countries like China and Japan, and this is certainly not the narrative that Moscow itself prefers to promote. In a speech given in September 2014, Prime Minister Medvedev stressed that "history shows that any attempts to put pressure on Russia have been unsuccessful," and that "without a

\footnotetext{
148 ibid, 78.

${ }^{149}$ Sarah Lain, "The Bear and the Dragon." [The RUSI Journal 160.1 (2015)] 70.

${ }^{150}$ ibid, 75.
} 
doubt," the "growth" of Russia's "role in the Asian region" actually "contributes" to the country "raising" its "authority" in "other places as well, including in the West." 151

The U.S.-China Economic and Security Review Commission took a more nuanced view, noting that "a simplistic view of the May 2014 deal is that Russia, under political and economic duress, final acquiesced to Chinese demands," when "in reality, the talks" actually "exacted compromises from both sides."152 The commission argued that the deal actually gave Russia a good deal of leverage, and that "in the long run" European nations "could be affected by Russia’s 'Asia pivot," for "with China now buying Russian gas supplies, Moscow could exert further pressure on Kiev, with less concern about upsetting its European clients." $" 153$

Others have been more bold in their predictions, with Jing-Yun Hsu and Jenn-Jaw Soong writing that, "economic and trade relations between China and Russia have developed at a fast rate against the backdrop of the global economic slump." "I54 "If the two states continue to cooperate in this way," they argue, "an energy partnership between them" could "challenge the future balance of world power," and may ultimately result in "a changing of the world order."'155

So what does the development of this pivot truly represent? Are the accounts of Russian weakness overstated as Medvedev would have his audience believe, and is there more parity in the relationship between Russia and China, as the Commission suggests? Does this emerging partnership represent, as Hsu and Soong would argue, a potential revision in the world order?

\footnotetext{
151 "Medvedev: Russia Won't Close Its Economy, Just Turning to Asia." [Moscow Times. The Moscow Times, 19 Sept. 2014]

${ }^{152}$ Iacob Koch-Weser, and Craig Murray, "The China-Russia Gas Deal: Background and Implications for the Broader Relationship," [U.S.-China Economic and Security Review Commission (2014),] 10.

153 ibid, 19-20.

${ }^{154}$ Jing-Yun Hsu and Jenn-Jaw Soong, "Development of China-Russia Relations (1949-2011)," [Chinese Economy 47.3 (2014),] 86 .

155 ibid, 86.
} 


\section{$\underline{\text { Analysis }}$}

In an exhaustively thorough 2015 report, the Oxford Institute of Energy Studies found that "the outlook for Chinese gas supply and demand balance remains very unclear on both sides of the equation," for "Chinese demand has slowed recently, with forecasts for 2020 being downgraded sharply," while at the same time "uncertainties" remain regarding "shale gas development." 156 The authors conclude, "although the pivot to Asia can provide some diversification for Russian gas exports over the longer term, it is unlikely to offer the strong insurance policy that Russia desires," and furthermore, "any threat to European supply that it theoretically implied is already being seen as relatively empty."157

If the pivot towards Asia, and more specifically China is, as the report indicates, less than a panacea for Russia's current troubles, then it seems unlikely that a deepening partnership with China would result in equal parity for both sides, and even more unlikely that such a relationship would result in any major revision in world order. However, the fact that Russia would sign such agreements even at a relative disadvantage, speaks volumes both about the role of energy rents in sustaining the state, and the relative position of weakness from which the country is currently forced to negotiate.

Russia certainly has not fallen so far that it is without any bargaining chips on the world stage. Indeed, recent events in Syria, including talks between Russia and Saudi Arabia regarding potential cuts in production in exchange for the withdrawal of Russian support for Assad, demonstrate that there remains a number of diplomatic, economic, and military tools at the

\footnotetext{
${ }^{156}$ James Henderson, and Tatiana Mitrova. "The Political and Commercial Dynamics of Russia's Gas Export Strategy." [The Oxford Institute of Energy Studies (2015),] 76.

157 ibid, 76-77.
} 
country's disposal. ${ }^{158}$ However, these recent developments, including the deal with China, have forced Russia to show its hand, and that hand is considerably weaker than many originally expected. While there is never any guarantees in international politics, it is safe to say that if Russia's current patterns of behavior continue, especially as it relates to the overreliance on rents as a means of consolidating control, the country's instability will become an even more profound issue for the Kremlin.

It is only through reform, not of its status as a rentier state, but of where those rents are directed and to what purpose, that Russia can truly gain the stability it seeks, and given the current leadership, such reform seems unlikely. It seems more likely that Russia will continue on its current path of instability, into an increasingly unequal partnership with Asian countries such as China and Japan, and paradoxically away from the self-reliance and independence that Putin and his advisors have sought for so long.

For the United States and the European Union especially, if this analysis is correct, it means that economic tools such as sanctions, which increase pressure on this weakness, may in fact prove to be the most successful means of reducing Russian leverage on the world stage, and ultimately, in mitigating Russian power. Though this strategy may not yield immediate effects as a short term solution, the long term trends in Russia's use of oil and gas rents means that this instability will only become more pronounced, creating a much higher likelihood that these economic pressures will successfully work to contain Russian influence in the future.

\footnotetext{
${ }^{158}$ Mark Mazzetti, Eric Schmitt, and David. "Saudi Oil Is Seen as Lever to Pry Russian Support From Syria’s Assad." [The New York Times. The New York Times, 03 Feb. 2015.]
} 


\section{Conclusion}

Russia's world power status has seen a resurgence given its economic clout and wealth of natural resources. However, this renewed prominence is built on a fragile foundation that will ultimately prove to be unsustainable. A negotiated reading of Russia's status as a rentier state provides an understanding of just how precarious the country's current position remains, not because of the rents themselves, but because they are currently being used by Putin to consolidate control and maintain stability rather than to promote growth and economic development. As a number of scholars have noted, reforming how those rents are used could truly transform Russian society and place the country on a stable, level path towards regaining true power on the world stage. However, Putin is not willing to sacrifice his current foreign policy aims, built as they are on this unstable foundation, for the long term stability that such reforms would provide.

As a result, it is likely that Russia will continue down this path of instability, propped up by the oil and gas rents, until even those rents are no longer enough. As the recent deal with China indicates, that day may be coming sooner than some might think. Already, there are strong indicators that Russia is beginning to operate out of a position of weakness, especially in relation to its shifting partnerships with the Asian countries. The major question moving forward then is not if this moment of collapse will come, but how the Russian leadership will respond when Russia's house of cards does finally fall.

The decision to pivot towards Asia is strategic not because of any immediate economic implications, but because of the quiet truth that underlies the current state of Russian foreign policy. Kudrin's warning showed remarkable foresight about the dangers of using Russia's oil 
and gas industry to prop up such foreign policy aims, and his predictions continue to ring true. In using these rents to consolidate control and gain power for his foreign policy decisions, Putin has doomed Russia's future foreign policy to in turn be controlled by those rents, leaving the country with a lasting legacy of instability and weakness that will continue to affect both negotiations and the necessity of an Eastward pivot in the decades to come. 


\section{Charts \& Graphs}

\section{Figure 1. Rent Distributions}

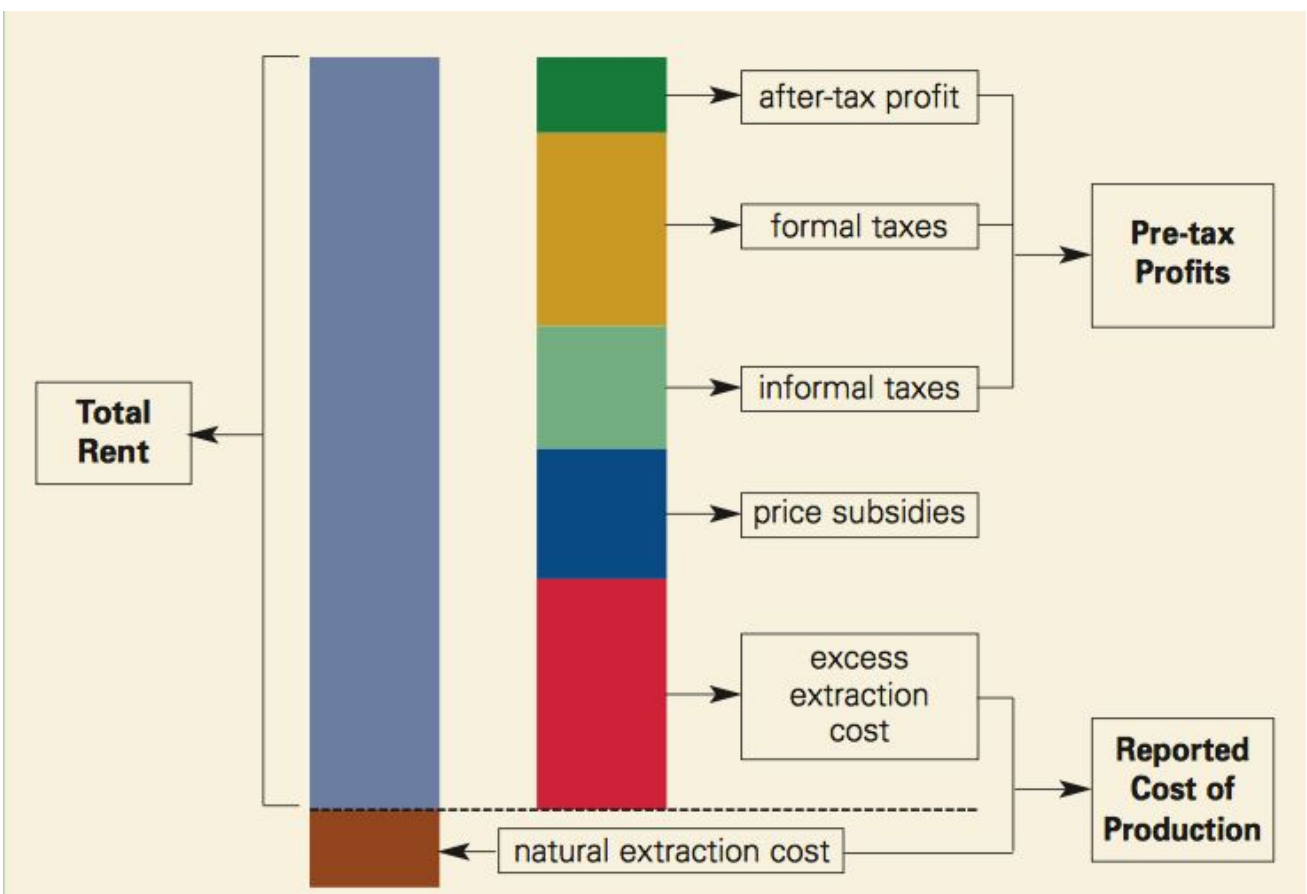

Source: Clifford G. Gaddy and Barry W. Ickes, "Resource Rents and the Russian Economy," Eurasian Geography and Economy (November 2005).

Figure 2. Russia's Gas Exports by Percentage (EIA 2015)

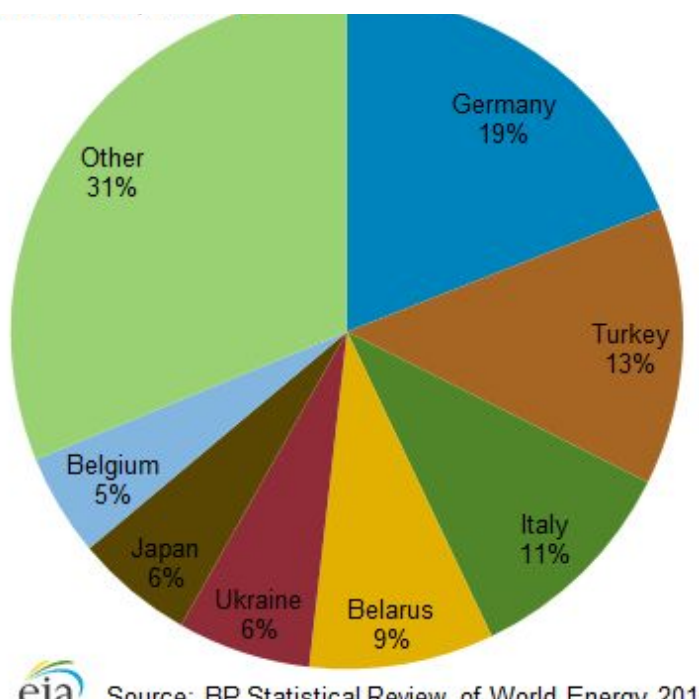


Figure 3. Russia's Oil Exports (EIA 2015)

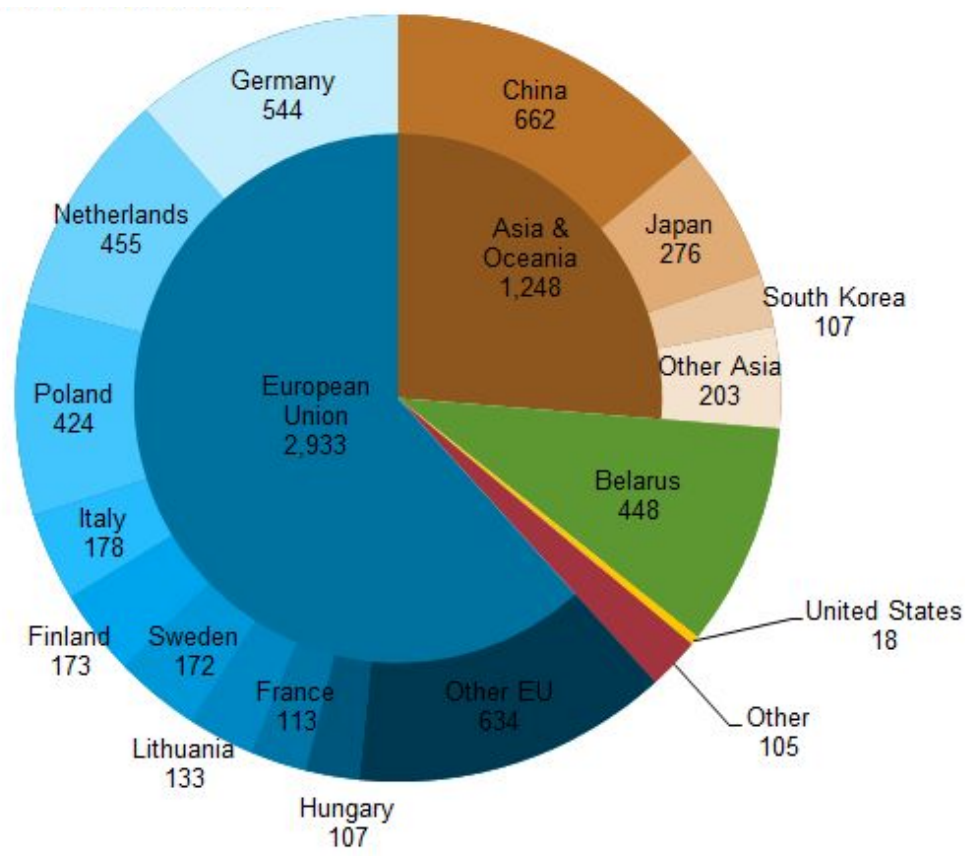

Sia Source: U.S. Energy Information Administration based on Federal Customs Service
of Russia and reporting countries' import statistics, Global Trade Information Service 
Stivers 39

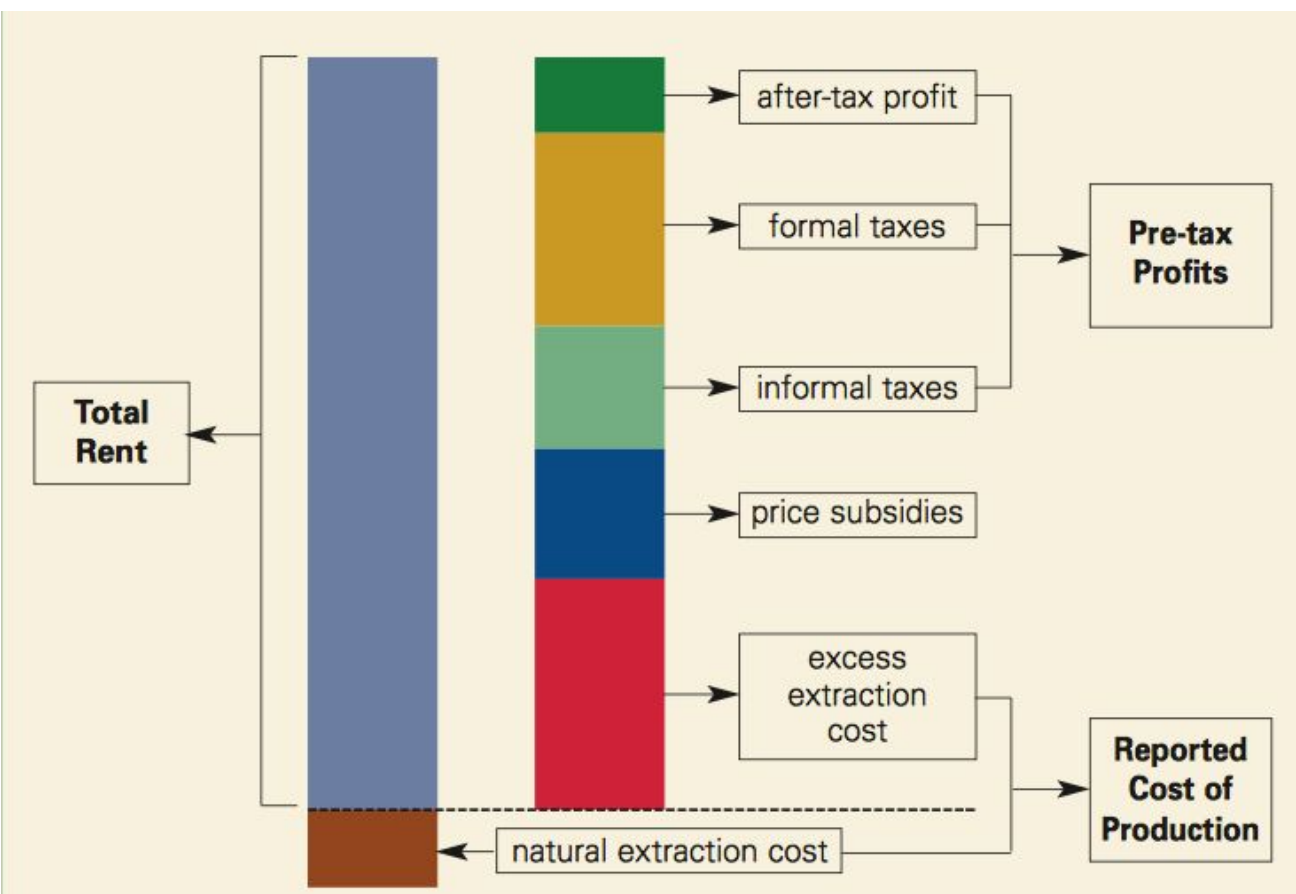

Source: Clifford G. Gaddy and Barry W. Ickes, "Resource Rents and the Russian Economy," Eurasian Geography and Economy (November 2005). 


\section{Bibliography}

Aron, Leon. "The Political Economy of Russian Oil and Gas." AEI. American Enterprise Institute, 29 May 2013. Web.

Barnato, Katy. "Why Russia Sanctions Are Here for the Long-haul." CNBC. CNBC, 05 Oct. 2015. Web.

Beblawi, Hazem. "The Rentier State in the Arab World”. Arab Studies Quarterly 9.4 (1987): 383-398.

"Concept of the Foreign Policy of the Russian Federation," Ministry of Foreign Affairs of the Russian Federation, 2013.

Cunningham, Nick. "Russia And China’s Growing Energy Relationship." Oilprice.com. OilPrice, 28 Jan. 2015. Web.

"Crude Oil Prices Peaked Early in 2012." EIA: Independent Statistics and Analysis. U.S. Energy Information Administration, 21 Aug. 2012.

Daiss, Tim. "U.S.-Led Sanctions Squeeze Massive Russian Gas Project, But Chinese Funds May Hold The Answer." Forbes. Forbes Magazine, 18 Nov. 2015. Web.

Dunning, Thad, Crude Democracy: Natural Resource Wealth and Political Regimes. Cambridge: Cambridge UP, 2008: 1-25.

Dunning, Thad, "Resource Dependence, Economic Performance, and Political Stability." Journal of Conflict Resolution 49 (4): 451-82.

Finon, Dominique and Catherine Locatelli. "Russian and European Gas Interdependence. Can Market Forces Balance out Geopolitics?" Elsevier, 2008, 36 (1), pp.423-442.

Gel'man, Vladimir, and O. Marganiia-. Resource Curse and Post-Soviet Eurasia: Oil, Gas, and Modernization. Lanham: Lexington, 2010.

Goldman, Marshall I. Petrostate: Putin, Power, and the New Russia. Oxford: Oxford UP, 2008.

Golubkova, Katya. "Russia's Rosneft in Talks to Allow China into Offshore Arctic Projects." Reuters. Thomson Reuters, 16 Nov. 2015. Web.

Guriev, Sergei. "Corruption Has Laid Waste to the Russian Economy," Financial Times, 2 Apr. 2014. 
Gustafson, Thane. Wheel of Fortune: The Battle for Oil and Power in Russia. Boston: Belknap, 2012.

Haber, Stephen and Victor A. Menaldo, "Natural Resources in Latin America: Neither Curse Nor Blessing," Oxford Handbook of Latin American Political Economy (2012): 1-21.

Hedenskog, Jakob and Robert L. Larsson, "Russian Leverage on the CIS and the Baltic States," FOI-Swedish Defense Research Agency, (2007): 1-138.

Henderson, James, and Tatiana Mitrova. "The Political and Commercial Dynamics of Russia's Gas Export Strategy." The Oxford Institute of Energy Studies (2015): 1-82.

Hill, Fiona. "Mr. Putin and the Art of the Offensive Defense: Observations on the Crisis in Ukraine and Crimea (Part Two)." The Brookings Institution. Brookings Institution, 16 Mar. 2014. Web.

Högselius, Per. Red Gas: Russia and the Origins of European Energy Dependence. New York: Palgrave Macmillan, 2013.

Hsu, Jing-Yun, and Jenn-Jaw Soong. "Development of China-Russia Relations (1949-2011)." Chinese Economy 47.3 (2014): 70-87.

Hutcheson, Derek S., and Bo Petersson. "The Three 'pillars of Putinism' and Their Role in the Crisis in Ukraine." Swedish Network for European Studies in Political Science (SNES) Annual Conference (2015): 1-27. Web.

"Japan's 2015 Crude Imports from Russia May Hit Record High." Reuters. Thomson Reuters, 11 Mar. 2015. Web.

Karl, Terry Lynn. The Paradox of Plenty: Oil Booms and Petro-states. Berkeley: U of California, 1997.

Kliment, Alexander. "Putin's Fairy Tale." Foreign Affairs. 28 Oct. 2015.

Koch-Weser, Iacob, and Craig Murray. "The China-Russia Gas Deal: Background and Implications for the Broader Relationship." U.S.-China Economic and Security Review Commission (2014): 1-29.

Kouchaksaraei, Mehrzad Javadi and Mohammad Reevany Bustami, "Structural Review of Rent Government and Its Effect on Democracy Process." Canadian Social Science, 8.6 (2012): 33-38.

"Kremlin Pivot to China Slowed as Projects Delayed." Reuters. Thomson Reuters, 27 Aug. 2015. Web. 
Kuchins, Andrew C. "Russia and the CIS in 2014: A Rather Bad Year." Asian Survey 55.1 (2015): 148-56.

Lain, Sarah. "The Bear and the Dragon." The RUSI Journal 160.1 (2015): 68-77.

Lally, Kathy, and Will Englund. "Putin Wins Election as Russian President; Opponents Claim Widespread Fraud." Washington Post. The Washington Post, 4 Mar. 2012.

Lee, Rensselaer W., and Artyom Lukin. Russia's Far East: New Dynamics in Asia Pacific and beyond. Boulder: Lynne Rienner, 2016. Print.

Lewis, Barbara, and Nerijus Adomaitis. "Norway Overtakes Russia as Western Europe's Top Gas Supplier." Reuters. Thomson Reuters, 22 May 2015. Web.

Luciani, Giacomo. "Allocation vs. Production States: A Theoretical Framework." The Arab State. Berkeley: U of California, 1990.

Luong, Pauline Jones, and Erika Weinthal. Oil Is Not a Curse: Ownership Structure and Institutions in Soviet Successor States. New York: Cambridge UP, 2010.

Mankoff, Jeffrey. "Russia's Asia Pivot: Confrontation or Cooperation?" Asia Policy 19.1 (2015): 65-87.

Mazneva, Elena, and Dina Khrennikova. "Putin's China Energy Deals May Hide Paper Tigers as Growth Slows." Bloomberg.com. Bloomberg, 4 Sept. 2015. Web.

Mazzetti, Mark, Eric Schmitt, and David D Kirkpatrick, "Saudi Oil Is Seen as Lever to Pry Russian Support From Syria's Assad." The New York Times. The New York Times, 03 Feb. 2015.

"Medvedev: Russia Won't Close Its Economy, Just Turning to Asia." Moscow Times. The Moscow Times, 19 Sept. 2014.

Mills, Laura. "Russia Joins WTO after 18 Years of Negotiations." USA Today. USA Today, 22 Aug. 2012.

"Oil and Natural Gas Sales Accounted for 68\% of Russia's Total Export Revenues in 2013." U.S. Energy Information Administration. EIA Independent Statistics and Analysis, 23 July 2014.

Olcott, Martha Brill. "The Energy Dimensions in Russian Global Strategy: Vladimir Putin and the Geopolitics of Oil." James A Baker III Institute of Public Policy (2004): 1-40. 
Ross, Michael L. "Does Oil Hinder Democracy?" World Pol. World Politics 53.03 (2001): $325-61$.

"Russia, China Discuss Localization of Manufacturing Some Types of Equipment in Russia." TASS. TASS16, 16 Nov. 2015. Web.

"Russia Races Past Saudi Arabia in Tussle for Chinese Oil Market." Bloomberg.com. Bloomberg, 21 Oct. 2015. Web.

"Russia's Rosneft Offers Japan Chance to Join East Siberia, Far East Project." RigZone.com. RigZone, 6 Dec. 2015. Web.

Sachs, Jeffrey, and Andrew Warner. "Natural Resource Abundance and Economic Growth." Harvard Institute for International Development (1995): 1-36.

Sakwa, Richard. Power and Policy in Putin's Russia. Abingdon: Routledge, 2009.

Stulberg, Adam N. "Out of Gas?: Russia, Ukraine, Europe, and the Changing Geopolitics of Natural Gas." Problems of Post-Communism 62.2 (2015): 112-30.

Tartar, Andre, and Anna Andrianova. "Russian Recession Risk Seen at Record as Oil Saps Economy." Bloomberg.com. Bloomberg, 27 Nov. 2014.

"The Russian Federation," The Brookings Foreign Policy Studies Energy Security Series. Washington D.C.: Brookings Institution, 2006.

"Ukraine and Russia Sanctions." U.S. Department of State. U.S. Department of State, 2015.

"Volume of Trade between Russia and Japan down by 38\% in 10 Months 2015." TASS. TASS, 19 Nov. 2015. Web.

Wiktorowicz, Quintan. "The Limits of Democracy in the Middle East: The Case of Jordan". Middle East Journal 53.4 (1999): 606-620.

Wright, Gavin "Resource-based Growth Then and Now," Stanford University, June 2001: 1-40. 